\title{
Pola kanker tiroid periode Juli 2013 - Juni 2016 di RSUP Prof. Dr. R. D Kandou Manado
}

\author{
${ }^{1}$ Yolanda Parura \\ ${ }^{2}$ Victor Pontoh \\ ${ }^{2}$ Marselus Merung \\ ${ }^{1}$ Kandidat Skripsi Fakultas Kedokteran Universitas Sam Ratulangi Manado \\ ${ }^{2}$ Bagian Bedah RSUP Prof. Dr. R. D. Kandou Manado \\ Email: Yolanda.parura@gmail.com
}

\begin{abstract}
Thyroid cancer is a common malignant disease found in endocrine system and is increasing in incidence every year, in Indonesia found around 9 from 10 malignancy. Based on histopathological types, thyroid carcinomas are divided into papillary carcinoma, follicular carcinoma, medullary carcinoma, and anaplastic carcinomas. The most common are papillary carcinoma and then follicular carcinoma. Factors that can influence the histopathological type of thyroid carcinomas is geographical factor, which most commonly found in mountainous areas. Thyroid cancer is rare in men, most often in women with a ratio of 1: 3. Conclusion: Female gender, mountainous terrain and adulthood to older people who suffered most thyroid cancer.
\end{abstract}

Keywords: thyroid cancer

\begin{abstract}
Abstrak: Kanker tiroid penyakit keganasan tersering ditemukan pada sistim endokrin dan insidennya meningkat setiap tahun, di Indonesia menempati urutan 9 dari 10 keganasan yang sering ditemukan. Berdasarkan gambaran histopatologinya, karsinoma tiroid dibagi menjadi tipe papiler, folikuler, meduler, dan anaplastik. Kasus terbanyak adalah karsinoma tiroid papiler dan terbanyak kedua adalah karsinoma tiroid folikular. Salah satu faktor yang mempengaruhi gambaran histopatologi karsinoma tiroid adalah keadaan geografis, dimana paling banyak ditemukan pada daerah pegunungan. Kanker tiroid jarang terjadi pada lakilaki, paling sering pada perempuan dengan perbandingan 1:3. Simpulan: Jenis kelamin perempuan, daerah pegunungan dan usia dewasa sampai lanjut usia yang paling banyak menderita kanker tiroid.
\end{abstract}

Kata kunci: kanker tiroid

Kanker tiroid merupakan penyakit keganasan yang tidak jarang ditemukan. Sebagian besar pertumbuhan dan perjalanan penyakit lambat, sehingga morbiditas dan mortalitasnya rendah namun ada yang pertumbuhannya sangat cepat dengan prognosa yang fatal. ${ }^{1,2}$ Kanker tiroid merupakan kelenjar tiroid yang berada pada bagian depan leher sedikit di bawah laring berbentuk kupukupu. Terjadi $0,85 \%$ dan 2,5\% dari seluruh keganasan kanker tiroid pada laki-laki dan perempuan dengan perbandingan 1:3. Dengan kata lain kanker tiroid lebih sering terjadi pada perempuan. Umumnya, kanker tiroid paling sering muncul pada usia 20-50 tahun, namun kanker ini dapat terjadi pada semua usia. $^{3}$

Angka kejadian karsinoma tiroid menurut data American Cancer Society diperkirakan mencapai 44.670 kasus baru pada tahun 2010. ${ }^{4}$ Dan data terbaru dari penderita kanker tiroid di Amerika Serikat pada tahun 2014 berjumlah 62.980 kasus 
baru dan terdapat 1.890 kematian diakibatkan karena kanker tiroid. ${ }^{5}$

Di Indonesia dari registrasi Perhimpunan Dokter Spesialis Patologi Indonesia didapatkan kanker tiroid menempati urutan ke 9 dari 10 kanker terbanyak $(4,43 \%){ }^{6}$ Di Rumah Sakit Dr. Cipto Mangunkusumo Jakarta, termasuk urutan yang ke lima setelah keganasan jenis lainnya. $^{7}$

Berdasarkan gambaran histopatologi karsinoma tiroid dibagi menjadi 4 tipe beserta dengan angka kejadian yang bervariasi, yaitu: tipe papilar $60 \%$, tipe folikular 20-30\%, tipe medular 5-10\%, tipe anaplastic 5-10\%. ${ }^{8}$ Sifat kanker tiroid umumnya berupa nodul tunggal, keras, tidak rata, sedangkan fungsinya kurang baik jika dibandingkan dengan fungsi jaringan tiroid di sekitarnya. ${ }^{9}$

Terdapat dua klasifikasi tipe kanker tiroid berdasarkan tingkat keganasannya yaitu jinak dan ganas. Kanker tiroid yang jinak tidak akan mengganggu aktivitas maupun fungsi bagian tubuh lainya, sedangkan pada kanker tiroid yang ganas sel kanker tersebut akan mengganggu fungsi tubuh dan akan menyebar keseluruh tubuh secara sporadik sehingga dapat menyebabkan kematian. ${ }^{3}$ Sifat kanker tiroid pada umumnya berupa nodul tunggal, keras, tidak rata, sedangkan fungsinya kurang baik jika dibandingkan dengan fungsi jaringan tiroid sekitarnya. ${ }^{10}$

Nodul tiroid amat sering ditemukan pada pasien, yang umumnya benigna. Kurang dari $5 \%$ bersifat maligna. Sebagian besar nodul-nodul (90\% sampai 95\%) adalah jinak (non kanker). ${ }^{11}$ Ada beberapa faktor dianggap mempunyai peranan yang terkait dengan etiopatogenesis kanker tiroid seperti : defisiensi iodium, radiasi, fakor genetic dan hormon reproduksi. Radiasi (eksternal) merupakan faktor paling penting yang dapat menimbulkan kerusakan gen. ${ }^{12}$ Berdasarkan dengan uraian di atas bahwa sebenarnya di Indonesia sendiri masih kurang data atau lebih tepatnya belum terdapat data yang lengkap tentang kasus penderita kanker tiroid. Maka penulis akan melakukan penelitian untuk mengetahui angka kejadian kanker tiroid di RSUP Prof. Dr. R. D. Kandou Manado periode Juli 2013 sampai dengan Juni 2016 berdasarkan epidemiologi atau angka kejadian, jenis kelamin, tempat tinggal, umur dan histopatologi nya.

\section{METODE PENELITIAN}

Penelitian yang dilakukan bersifat deskriptif retrospektif dengan mengambil data di Instalasi Rekam Medik dan bagian Patologi Anatomi RSUP Prof. DR. R .D. Kandou Manado. Penelitian dilakukan pada bulan Oktober sampai November 2016. Sampel penelitian adalah pasien kanker tiroid di RSUP Prof. DR. R. D. Kandou Manado periode Juli 2013 sampai dengan Juni 2016 dengan memperhatikan kriteria inklusi: pasien yang didiagnosa menderita kanker tiroid disertai hasil pemeriksaan patologi anatomi di RSUP Prof. DR. R. D. Kandou Manado periode Juli 2013 - Juni 2016. Kriteria eksklusi : pasien yang menderita kanker tiroid yang dilakukan pemeriksaan klinis saja tapi tidak dilengkapi hasil pemeriksaan patologi anatomi di RSUP Prof. DR. R. D. Kandou Manado periode Juli 2013 - Juni 2016.

\section{HASIL PENELITIAN}

Berdasarkan hasil penelitian yang penulis lakukan di bagian rekam medik dan patologi anatomi RSUP Prof. Dr. R. D. Kandou Manado didapatkan data penderita kanker tiroid periode Juli 2013 - Juni 2016 adalah sebanyak 62 penderita.

Berdasarkan Tabel 1 memperlihatkan 62 penderita kanker tiroid dengan jenis kelamin laki-laki yaitu sebanyak 23 orang $(37,1 \%)$ dan perempuan sebanyak 39 orang $(62,9 \%)$.

Tabel 1. Distribusi jumlah penderita kanker tiroid menurut jenis kelamin

\begin{tabular}{ccc}
\hline $\begin{array}{c}\text { Jenis } \\
\text { kelamin }\end{array}$ & $\begin{array}{c}\text { Jumlah } \\
\text { penderita }\end{array}$ & $\mathbf{\%}$ \\
\hline Laki-laki & 23 & 37,1 \\
Perempuan & 39 & 62,9 \\
Total & 62 & 100
\end{tabular}


Berdasarkan Tabel 2 diatas dapat dilihat frekuensi penderita kanker tiroid menurut umur, golongan umur $<20$ tahun sebanyak 1 orang $(1,6 \%)$, dimana 1 orang $(1,6 \%)$ dengan karsinoma papilar, 0 orang $(0,0 \%)$ dengan karsinoma folikular, 0 orang $(0,0 \%)$ dengan karsinoma medular, dan 0 orang $(0,0 \%)$ dengan karsinoma naplastic. Golongan umur 21-40 tahun sebanyak 11 orang $(17,7 \%)$, dimana 9 orang $(14,5 \%)$ dengan karsinoma papilar, 2 orang $(3,2 \%)$ dengan karsinoma folikular, 0 orang $(0,0 \%)$ dengan karsinoma medular, dan 0 orang $(0,0 \%)$ dengan karsinoma anaplastik. Golongan umur 41-60 sebanyak 27 orang $(43,5 \%)$, dimana 14 orang $(22,6 \%)$ dengan karsinoma papilar, 8 orang $(12,9 \%)$ dengan karsinoma folikular, 1 orang $(1,6 \%)$ dengan karsinoma medular, dan 4 orang $(6,5 \%)$ dengan karsinoma anaplastic. Golongan umur $>60$ tahun sebanyak 23 orang $(37,1 \%)$, dimana 16 orang $(25,8 \%)$ dengan karsinoma papilar, 4 orang $(6,5 \%)$ dengan karsinoma folikular, 0 orang $(0,0 \%)$ dengan karsinoma medular, dan 3 orang $(4,8 \%)$ dengan karsinoma anaplastik.

Dari data pada Tabel 3 diperoleh penderita kanker tiroid selama 3 tahun berturut-turut yaitu pada periode Juli 2013 - Juni 2014 sebanyak 11 orang (17,4\%), periode Juli 2014 - Juni 2015 sebanyak 27 orang (43,5\%), dan periode Juli 2015 - Juni 2016 sebanyak 24 orang $(38,7 \%)$

Tabel 2. Distribusi jumlah penderita kanker tiroid menurut umur

\begin{tabular}{ccccccccccc}
\hline \multirow{2}{*}{ Umur } & \multicolumn{2}{c}{ Papilar } & \multicolumn{2}{c}{ Folikular } & \multicolumn{2}{c}{ Medular } & \multicolumn{2}{c}{ Anaplastik } & \multirow{2}{*}{ Jumlah } & \% \\
\cline { 2 - 9 } & $\mathrm{N}$ & $\%$ & $\mathrm{~N}$ & $\%$ & $\mathrm{~N}$ & $\%$ & $\mathrm{~N}$ & $\%$ & & \\
\hline$<20$ & 1 & $1,6 \%$ & 0 & $0,0 \%$ & 0 & $0,0 \%$ & 0 & $0,0 \%$ & 1 & $1,6 \%$ \\
\hline $21-40$ & 9 & $14,5 \%$ & 2 & $3,2 \%$ & 0 & $0,0 \%$ & 0 & $0,0 \%$ & 11 & $17,7 \%$ \\
\hline $41-60$ & 14 & $22,6 \%$ & 8 & $12,9 \%$ & 1 & $1,6 \%$ & 4 & $6,5 \%$ & 27 & $43,5 \%$ \\
\hline$>60$ & 16 & $25,8 \%$ & 4 & $6,5 \%$ & 0 & $0,0 \%$ & 3 & $4,8 \%$ & 23 & $37,1 \%$ \\
\hline Total & 40 & $64,5 \%$ & 14 & $22,6 \%$ & 1 & $1,6 \%$ & 7 & $11,3 \%$ & 62 & $100 \%$ \\
\hline
\end{tabular}

Tabel 3. Angka kejadian kanker tiroid menurut tahun

\begin{tabular}{cccccc}
\hline Periode & $\begin{array}{c}\text { Karsinoma } \\
\text { Papilar }\end{array}$ & $\begin{array}{c}\text { Karsinoma } \\
\text { Folikular }\end{array}$ & $\begin{array}{c}\text { Karsinoma } \\
\text { Medular }\end{array}$ & $\begin{array}{c}\text { Karsinoma } \\
\text { Anaplastik }\end{array}$ & Jumlah \\
\hline $\begin{array}{c}\text { Juli } 2013-\text { Juni } \\
2014\end{array}$ & $5(8,1 \%)$ & $3(4,8 \%)$ & $1(1,6 \%)$ & $2(3,2 \%)$ & $11(17,4 \%)$ \\
\hline $\begin{array}{c}\text { Juli } 2014-\text { Juni } \\
2015\end{array}$ & $15(24,2 \%)$ & $8(12,9 \%)$ & $0(0,0 \%)$ & $4(6,5 \%)$ & $27(43,5 \%)$ \\
\hline $\begin{array}{c}\text { Juli } 2015-\text { Juni } \\
2016\end{array}$ & $20(32,3 \%)$ & $3(4,8 \%)$ & $0(0,0 \%)$ & $1(1,6 \%)$ & $24(38,7 \%)$ \\
\hline Total & $40(64,5 \%)$ & $14(22,6 \%)$ & $1(1,6 \%)$ & $7(11,3 \%)$ & $62(100 \%)$ \\
\hline
\end{tabular}

Tabel 4 memperlihatkan bahwa penderita dengan kanker tiroid yang tinggal di daerah pegunungan sebanyak 30 orang $(48,4 \%)$, daerah pesisir pantai sebanyak 22 orang $(35,5 \%)$, dan data tempat tinggal yang tidak lengkap atau tidak diketahui sebanyak 10 orang $(16,1 \%)$.

Tabel 5 memperlihatkan distribusi frekuensi kanker tiroid menurut jenis histopatologik pada karsinoma papilar sebanyak 40 orang $(64,5 \%)$, karsinoma folikular sebanyak 14 orang $(22,6 \%)$, karsinoma medular sebanyak 1 orang
$(1,6 \%)$, dan karsinoma anaplastik sebayak 7 orang $(11,3 \%)$.

Tabel 4. Distribusi kanker tiroid menurut tempat tinggal

\begin{tabular}{ccc}
\hline Tempat tinggal & $\begin{array}{c}\text { Jumlah } \\
\text { penderita }\end{array}$ & $\%$ \\
\hline Pegunungan & 30 & 48,4 \\
Pesisir Pantai & 22 & 35,5 \\
Tidak Diketahui & 10 & 16,1 \\
Total & 62 & 100 \\
\hline
\end{tabular}


Tabel 5. Distribusi kanker tiroid menurut jenis histopatologi

\begin{tabular}{ccc}
\hline $\begin{array}{c}\text { Hasil Patologi } \\
\text { Anatomi }\end{array}$ & $\begin{array}{c}\text { Jumlah } \\
\text { Penderita }\end{array}$ & $\%$ \\
\hline Karsinoma Papilar & 40 & 64,5 \\
Karsinoma Folikular & 14 & 22,6 \\
Karsinoma Medular & 1 & 1,6 \\
Karsinoma Anaplastik & 7 & 11,3 \\
Total & 62 & 100 \\
\hline
\end{tabular}

\section{BAHASAN}

Berdasarkan hasil penelitian penulis yang bersifat deskriptif dapat ditemukan kanker tiroid di bagian rekam medik dan patologi anatomi RSUP Prof. Dr. R. D. Kandou Manado periode Juli 2013 - Juni 2016 sebanyak 62 penderita. Kanker tiroid yang ditemukan selama periode tersebut adalah karsinima papilar, karsinima folikular, karsinoma medular, dan karsinoma anaplastik. Dari data pada tabel 1 penggolongan jenis kelamin penderita kanker tiroid terbanyak adalah pada perempuan yaitu sebanyak 39 orang $(62,9 \%)$, sedangkan pada laki-laki yaitu sebanyak 23 orang $(37,1 \%)$. Hasil ini sesuai dengan Wartofsky L dan Kumar V dan yang menyatakan bahwa prevalensi kanker tiroid lebih banyak terjadi pada kalangan perempuan dari pada laki-laki. Dari seluruh keganasan di Amerika Serikat dengan jumlah $0,85 \%$ pada pria dan $2,6 \%$ pada wanita. Hal ini disebabkan pengaruh hormon pada perempuan merupakan salah satu faktor predisposisi meningkatnya jumlah pasien perempuan dibandingkan laki-laki. Estrogen dapat meningkatkan kadar thyroid binding globulin (TBG) yang bekerja sebagai transpor T4 dan T3 dalam darah sehingga terjadi penurunan kadar T4 bebas dan T3 bebas. Hal ini menstimulasi TSH sehingga terjadi hiperplasia kelenjar sebagai mekanisme kompensasi membentuk lebih banyak hormon tiroid agar kadar T4 dan T3 serum dapat kembali normal. ${ }^{13,14}$

Penggolongan umur pada tabel 2 memperlihatkan bahwa penderita kanker tiroid paling banyak terjadi pada pasien golongan umur 41-60 tahun dan $>60$ tahun, disusul golongan umur 21-40 tahun kemudian golongan umur $<20$ tahun. Hal ini sesuai dengan penelitian yang dilakukan oleh Pasaribu ET dan Adiputra PAT yang mengatakan bahwa kanker tiroid lebih banyak menyerang umur dewasa hingga lanjut usia yaitu dimana terjadi peningkatan pada golongan usia 40-65 tahun. Insiden karsinoma tiroid terjadi seiring dengan bertambahnya usia, kanker tiroid sangat jarang pada anak-anak usia di bawah 15 tahun.

Pada tabel 3 memperlihatkan angka kejadian kanker tiroid selama 3 tahun berturut-turut yaitu pada tahun pertama (Juli 2013-Juni 2014) terdapat 11 penderita, tahun kedua (Juli 2014-Juni 2015) terdapat 27 penderita, sedangkan tahun ketiga (Juli 2015-Juni 2016) terdapat 24 penderita. Dari data tersebut menunjukan dimana tahun petama menuju tahun kedua mengalami peningkatan tetapi pada tahun ketiga adanya penurunan. Hal tersebut memiliki kesamaan dan juga adanya perbedaan pada kepustakaan dari dari Pellegriti G dan Putri $\mathrm{E}$ yang menyatakan bahwa insiden karsinoma tiroid selalu mengalami peningkatan setiap tahunnya dan peningkatanya lebih cepat karena faktor risiko yang mungkin berkontribusi pada peningkatan kejadian kanker tiroid, faktorfaktor risiko seperti: radiasi, intake iodium kurang, TSH meningkat, nodul tiroid, obesitas dan resistensi insulin, pengaruh diet, gaya hidup, dan lingkungan. ${ }^{15,16}$ Dan untuk perbedaannya dikarenakan dilakukannya pencegahan dan pengobatan diawal untuk menghindari terjadinya keganasan pada nodul tiroid dengan cara menghindari faktor-faktor risiko penyebab kanker tiroid.

Berdasarkan tabel 4 tentang distribusi penderita kanker tiroid berdasarkan tempat tinggal, kanker tiroid paling banyak terjadi di daerah pegunungan yaitu sebanyak $48,4 \%$, kemudian di daerah pesisir pantai yaitu sebanyak $35,5 \%$, dan ada $16,1 \%$ yang tidak diketahui atau tidak lengkap data tempat tinggal. Di kota Manado, sebagian besar wilayahnya terdiri dari daerah 
pegunungan, dimana kurang lebih 100 meter dari pantai sudah memasuki wilayah pegunungan. Hasil ini sesuai dengan Djokomoelyanto yang menyatakan bahwa sering terjadi atau diketemukan di daerah pegunungan di mana makanan yang dikonsumsi sangat tergantung pada produksi pangan setempat pada kondisi tanah yang miskin yodium. Prevalensi gondok berdasarkan letak geografis yang diolah berdasarkan prevalensi gondok pada anak sekolah menunjukkan bahwa prevalensi gondok tertinggi ditemukan di daerah dataran tinggi sebesar $30.3 \%$, disusul daerah dataran rendah $(8.7 \%)$ dan di daerah rawa hanya sebesar $2.8 \%$. Djokomoelyanto mengemukakan bahwa dataran tinggi atau pegunungan biasanya miskin akan yodium karena lapisan paling atas dari tanah yang mengandung yodium terkikis dari waktu ke waktu, sebaliknya tanah di dataran rendah kemungkinan terkikis lebih kecil sehingga diduga kandungan yodium masih normal. ${ }^{17}$ Selain itu, pola konsumsi masyarakat juga berhubungan dengan banyaknya kejadian tiroid di daerah pegunungan. Bahan pokok pembuat hormon tiroid adalah yodium yang terdapat di alam, terutama dari bahan makanan yang dari laut seperti rumput laut, ganggang laut, ikan laut dan sebagainya. Masyarakat yang tinggal di daerah pegunungan biasanya kurang mengonsumsi makanan yang tinggi yodium. ${ }^{18}$ Selain itu, ada 10 kasus yang data alamat pasien tidak dicantumkan. Hal ini disebabkan karena adanya pengisian status dan surat rujukan pemeriksaan yang tidak mencantumkan tempat tinggal penderita.

Penderita dengan kanker tiroid terbanyak berdasarkan data pada tabel 5 adalah karsinoma tiroid papilar yaitu sebanyak $64,5 \%$, diikuti oleh karsinoma folikular yaitu sebanyak $22,6 \%$, karsinoma anaplastik yaitu sebanyak 11,3\%, dan kemudian karsinoma medular yaitu sebanyak $1,6 \%$. Hasil penelitian ini sejalan dengan Altundag EM dan Oktahermoniza yang mengatakan bahwa jenis karsinoma tiroid yang paling sering ditemukan adalah karsinoma papilar sebanyak $80 \%$ dan karsinoma folikuler pada urutan kedua, serta yang paling jarang terjadi karsinoma medular dan anaplastik. Oktahermoniza juga menyatakan gambaran histopatologi terbanyak pada penelitiannya adalah tipe papilar yaitu 61 penderita $(52,1 \%)$ diikuti tipe folikular 49 penderita $(41,8 \%))^{6,19}$ Selain itu juga pada kepustakaan Haugen B menyatakan bahwa angka kejadian karsinoma papilar adalah sebanyak $80 \%$, karsinoma folikular sebanyak 10-15\%, karsinoma medular sebanyak 5\%, dan karsinoma anaplastik sebanyak $1-2 \% .^{20}$ Sedangkan pada penelitian ini hanya di temukan $64,5 \%$.

\section{SIMPULAN}

Kanker tiroid di RSUP Prof. Dr. R. D. Kandou manado paling banyak pada perempuan, dengan golongan umur 41-60 tahun, mengalami peningkatan pada tahun kedua periode Juli 2014 - Juni 2015 dan terjadi penurunan pada tahun ketiga, paling banyak penderita ditemukan dengan karsinoma papilar, dan tempat tinggal yang paling sering terjadi adalah daerah pegunungan.

\section{SARAN}

1. Diharapkan dengan mengetahui angka kejadian kanker tiroid dapat membantu tenaga medis dalam memberikan edukasi dan upaya preventif terhadap penderita kanker tiroid untuk dapat mengurangi angka kejadian kanker tiroid.

2. Arsip data rekam medik sebagai sumber data penelitian sebaiknya harus lebih lengkap dan jelas dan disimpan dengan baik meskipun sudah lebih dari 3 tahun sehingga memudahkan peneliti untuk melakukan penelitian.

3. Pada rekam medik sebaiknya dicantumkan surat keterangan diagnosa berdasarkan lab. Patologi-anatomi, untuk meningkatkan keakuratan dan kualitas penelitian.

4. Perlu dilakukan penelitan lebih lanjut untuk mengetahui penyebab turunnya angka kejadian pada kanker tiroid. 
DAFTAR PUSTAKA

1. Pasaribu ET. Epidemiologi dan Gambaran Klinis Kanker Tiroid. Divisi Onkologi Departemen Ilmu Bedah Fakultas Kedokteran Universitas Sumatera Utara - RS H Adam Malik, Medan. Jurnal Kedokteran Nusantara 2006;39:270-3.

2. Subakti I. Karsinoma Tiroid. Dalam: Sudoyo AW, Setiyohadi B, Alwi I, Simadibrata M, Setiati S, editor. Ilmu Penyakit Dalam jilid 3. Edisi 5. Jakarta: Interna Publishing; 2009. h. 2031-7.

3. Handayani SHS, Purnami SW. Pendekatan Metode Classification and Regression Tree untuk Diagnosis Tingkat Keganasan Kanker pada Pasien Kanker Tiroid. Jurnal Sains dan Seni Pomits. 2014;3:24-29.

4. Ellys, Kartika I, Aspitriani, Yuwono. Tingkat Ekspresi Galectin-3 Sebagai Penanda Lesi Jinak Dan Lesi Ganas Pada Tiroid. Jurnal Kedokteran dan Kesehatan. 2015;2:311-7.

5. American Cancer Society. Cancer Facts \& Figures 2014. Atlanta, Ga:American Cancer Society.2014.

6. Oktahermoniza, Harahap WA, Tofrizal, Rasyid R. Analisis Ketahanan Hidup Lima Tahun Kanker Tiroid yang Dikelola di RSUP Dr. M. Djamil Padang. Jurnal Kesehatan Andalas. 2013;2:151-7.

7. Tjindarbumi D. Karsinoma Tiroid. Dalam: Reksoprodjo S, editor. Kumpulan Kuliah Ilmu Bedah. Bagian Ilmu Bedah FKUI/ Rumah Sakit Dr. Cipto Mangunkusumo.h. 343-52.

8. Kruseman ACN, Velde CJHVD. Tumor Kelenjar Tiroid. Dalam: Velde CJHVD, Bosman FT, Wagener DJTh, editor. Onkologi. Edisi 5, direvisi. Panitia Kanker RSUP DR Sardjito Yogyakarta;1999.

9. Adiputra PAT. Karakteristik Penderita Kanker di Bagian Bedah Onkologi RSUP Sanglah Denpasar Tahun 20092012. Jurnal Medika Udayana. 2015;4:1-9.

10. Djokomoeljanto. Penyakit Kelenjar Gondok, Sebuah Tinjauan Populer. Dalam: Tony Suhartono TGDP, K Heri Nugroho, editor. 2 ed. Semarang: Badan Penerbit
Undip; 2011. h. 1-12, 51-60.

11. European Journal of Clinical Investigation. Characteristics of Thyroid Carcinomas in Aging Patients. 2001;30:147-53.

12. Buku Ajar Tiroidologi Klinik. Djokomoeljanto, editor. Semarang: Badan Penerbit Undip; 2009. h. 193216.

13. Maitra A, Kumar V. Sistem endokrin. In: Kumar V, Cotran RS, Robbins SL, editor. Patologi robbins volume 2. Edisi 7. Jakarta: EGC;2012. h. 818-24.

14. Wartofsky L. Increasing world incidence of thyroid cancer: Increased detection or higher radiation exposure. Hormones. 2010;9:103-8.

15. Putri E, Khambri D, Renita $S$. Hubungan Daerah Tempat Tinggal dengan Gambaran Histopatologi Karsinoma Tiroid pada Masyarakat Sumatera Barat. Jurnal Kesehatan Andalas. 2014; 3:147-50.

16. Pellegriti G, Frasca F, Regalbuto C, Squatrito S, Vigneri R. Worldwide Increasing Incidence of Thyroid Cancer : Update on Epidemiology and Risk Factors. Dalam : Rohan TE, editor. Journal of Cancer Epidemiology. Italy:2013;1-10.

17. Saidin S, Hubungan keadaan geografi dan lingkungan dengan gangguan akibat kurang yodium (GAKY). Pusat Penelitian dan Pengembangan Gizi dan Makanan, Bogor. Media Litbang Kesehatan. 2009;19:101-8.

18. Pramono B, Purnomo LB, Sinorita $H$. Gondok Endemik. Dalam: Setia S, Alwi I, Sudoyono AW, Simadibrata KM, Setiyohadi B, Syam AF, editor. Ilmu Penyakit Dalam jilid 2. Edisi 6. Jakarta: Interna Publishing; 2014. h. 2464-70.

19. Altundag EM dkk. Quercetin-Induced Cell Death in Human Papillary Thyroid Cancer (B-CPAP) Cells. Dalam : Francis GL, editor. Journal of Tyroid Research. Turkey:2016;1-10.

20. Haugen B, Tuttle M, Wartofsky L. Thyroid Cancer: The journal of clinical endocrinology and metabolism. Endocrine Society. 2011;91:1. 